\title{
Incidence of Vibrio during dermal and systemic infections of the spotted sand bass (Paralabrax maculatofasciatus Steindachner: 1868) in captivity
}

\section{Incidencia de Vibrio durante infecciones dérmicas y sistémicas de la cabrilla arenera (Paralabrax maculatofasciatus Steindachner: 1868) en cautiverio}

\author{
Sergio F. Martínez-Díaz* \\ Benjamín Anguas-Vélez \\ Centro Interdisciplinario de Ciencias Marinas (CICIMAR-IPN) \\ Playa El Conchalito s/n \\ Apartado postal 592 \\ La Paz, CP 23000, Baja California Sur, México \\ *E-mail:sdiaz@ipn.mx \\ Recibido en febrero de 2001; aceptado en julio de 2002
}

\begin{abstract}
The incidence of Vibrio in dermal and internal injuries was evaluated in captive broodstock of spotted sand bass, Paralablax maculatofasciatus. During haemorragic infections the associated bacteria were isolated on thiosulfate-citrate-bile-sucrose agar (TCBS) and on Marine Agar 2216. Isolates were presumptively identified and the pathogenicity was experimentally evaluated. Vibrio alginolyticus, $V$. cholerae, $V$. fluvialis, $V$. parahaemolyticus, $V$. vulnificus and Vibrio sp. were present in external injuries. Vibrio alginolyticus was consistently predominant in dermal injuries. Clinical signs recorded during the vibriosis outbreaks included hemorrhages and petechiae on body surfaces, which were most severe at the base of the pelvic fins and in the opercular region. Hemorrhages and necrosis were observed on the fins. Affected fish became inactive and anorexic. Internally, hemorrhages in the intestine and a pale liver were observed. During experimentally induced infections, the fish inoculated with $10^{8}$ cells of the strain $\mathrm{VPb}-\mathrm{C} 7$ (identified as $V$. alginolyticus) developed clinical signs and mortality was recorded.
\end{abstract}

Keywords: Vibrio alginolyticus, vibriosis, Paralabrax maculatofasciatus, fish disease.

\section{Resumen}

Se evaluó la incidencia de Vibrio en lesiones dérmicas e internas en lotes de reproductores de Paralablax maculatofasciatus mantenidos en cautiverio. Durante infecciones hemorrágicas las bacterias asociadas fueron aisladas en los medios tiosulfatocitrato-bilis-sucrosa (TCBS) y en Agar Marino 2216. Las cepas aisladas fueron identificadas de manera presuntiva y su patogenicidad fue evaluada experimentalmente. Vibrio alginolyticus, V. cholerae, $V$. fluvialis, $V$. parahaemolyticus, $V$. vulnificus, y Vibrio sp. estuvieron presentes en las lesiones externas. Vibrio alginolyticus fue consistentemente predominante en las lesiones dérmicas. Los signos clínicos registrados durante los brotes de vibriosis incluyeron hemorragias y petequia en las superficies corporales, las cuales fueron más severas en la base de las aletas pélvicas y sobre la región opercular. Sobre las aletas se observaron hemorragias y necrosis. Los peces afectados se volvieron inactivos y anoréxicos. Internamente se observaron hemorragias sobre el intestino y el hígado pálido. Durante las infecciones inducidas experimentalmente, los peces inoculados con $10^{8}$ células de la cepa $\mathrm{VPb}-\mathrm{C} 7$ (identificada como $\mathrm{V}$. Alginolyticus), se observo el desarrollo de signos clínicos y mortalidad.

Palabras clave: Vibrio alginolyticus, vibriosis, Paralabrax maculatofasciatus, enfermedades de peces.

\section{Introduction}

Several species of the genus Vibrio have been reported as the causal agent during diseases of marine organisms. In fish, Vibrio produces hemorrhagic septicaemia and can cause mass mortality during severe outbreaks. Vibriosis has been described as the principal factor of mortality of several wild and cultured fishes and it is responsible for significant economic losses in aquaculture (Sinderman, 1990).

\section{Introducción}

Varias especies del género Vibrio se han reportado como agentes causales en enfermedades de organismos marinos. En peces, Vibrio causa septicemia hemorrágica y puede causar mortalidades masivas durante brotes severos. La vibriosis ha sido descrita como el principal factor de mortalidad de muchos peces cultivados y silvestres y es responsable de perdidas económicas significativas para la acuacultura (Sinderman 1990). 
Vibrio spp. have been reported as pathogenic for fish, e.g. V. ordalii (Crosa et al., 1977), V. cholerae (Muroga et al., 1979), V. alginolyticus (Colorni et al., 1981), V. damsela (Love et al., 1981), V. vulnificus (Tison et al., 1982), V. charchariae (Grimes et al., 1985), Vibrio fisheri, V. parahaemolyticus and V. splendidus (Austin and Gibb, 1993), V. fluvialis (Xu et al., 1993; Zhan and Bohai, 1994), V. harveyi (Austin and Gibb, 1993; Deniz et al., 1993; Saeed, 1995; Ishimaru and Muroga, 1997), $V$. estuarianus, $V$. costicola, $V$. cincinatensis and $V$. salmonicida (Egidius et al., 1986; Austin and Austin, 1994) and $V$. trachiuri (Iwamoto et al., 1995). However, vibriosis is a disease associated with stressed environmental conditions such as changes in water temperature, salinity, handling, and low water quality, including oxygen depletion and eutrophication (Sinderman, 1990; Austin and Austin, 1987).

The spotted sand bass Paralabrax maculatofasciatus is a good candidate for aquaculture (Anguas-Velez et al., 2000; Martínez-Díaz et al., 2001). This species has been experimentally cultured in Mexico since 1991. Recent improvements in its culture reported by Anguas-Vélez et al. (2000) and ÁlvarezGonzález et al. (2001) strongly suggest the possibility to produce it commercially. However, there are no reports of main diseases of the spotted sand bass subject to intensive production. The purpose of this study was to evaluate the incidence of Vibrio as an infectious agent for spotted sand bass and as a risk factor in the culture of this species.

\section{Materials and methods}

\section{Culture conditions of Paralabrax maculatofasciatus}

Paralabrax maculatofasciatus is produced in pilot-scale at the facilities of the Centro Interdisciplinario de Ciencias Marinas (CICIMAR). Broodstock is collected from the wild using line and hook; spawning in the laboratory is induced through environmental control. Spawning and rearing until seed stage $(c a .10 \mathrm{~cm})$ is accomplished at indoor facilities using recirculating water systems and growth is accomplished in floating net cages. Each recirculating water system is equipped with mechanical and biological filters, skimer, UV-light and artificial photoperiod and temperature control. Aereation is provided in each tank by a blower through central air-stones. The broodstock is maintained in groups in 1100-L tanks (ca. 1.5 $\mathrm{g} \mathrm{L}^{-1}$ ). Fish are fed ad-libitum once a day with frozen squid and fish, draining the remaining feed and the fecal pellets.

\section{Sampling}

The study was made between 1991 and 1996 at CICIMAR. Each infection and outbreak that occurred in the juvenile and broodstok was routinely analyzed. Those infections to which the genus Vibrio was not associated were not considered in this report.

In the laboratory, the diseased fish were anesthetized with MS222 (Tricaine Spectrum ${ }^{\circledR}$ ) and dissected under aseptic
Vibrio spp. han sido reportadas como patógenos de peces, como por ejemplo, en $V$. ordalii (Crosa et al., 1977), $V$. cholerae (Muroga et al., 1979), V. alginolyticus (Colorni et al., 1981), V. damsela (Love et al., 1981), V. vulnificus (Tison et al., 1982), V. charchariae (Grimes et al., 1985), Vibrio fisheri, V. parahaemolyticus y V. splendidus (Austin y Gibb, 1993), V. fluvialis (Xu et al., 1993; Zhan y Bohai, 1994), V. harveyi (Austin y Gibb, 1993; Deniz et al., 1993; Saeed, 1995; Ishimaru y Muroga, 1997), $V$. estuarianus, V. costicola, $V$. cincinatensis y V. salmonicida (Egidius et al., 1986; Austin y Austin, 1994) y $V$. trachiuri (Iwamoto et al., 1995). Sin embargo, la vibriosis es una enfermedad asociada con condiciones ambientales estresantes como cambios en la temperatura del agua, salinidad, manipulación y baja calidad del agua, incluyendo la disminución en los niveles de oxigeno y eutrofización (Sinderman, 1990; Austin and Austin, 1987).

La cabrilla arenera Paralabrax maculatofasciatus es un buen candidato para acuacultura (Anguas-Velez et al., 2000; Martínez-Díaz et al., 2001). Esta especie ha sido cultivada experimentalmente desde 1991. Recientes mejoras en su cultivo reportadas por Anguas-Vélez et al. (2000) y ÁlvarezGonzález et al. (2001), sugieren fuertemente la posibilidad de una producción comercial. Sin embargo, no existen reportes sobre las principales enfermedades de la cabrilla durante la producción intensiva. El propósito de este estudio fue el de evaluar la incidencia de Vibrio como agente infeccioso para la cabrilla arenera y como un factor de riesgo en el cultivo de esta especie.

\section{Materiales y métodos}

\section{Condiciones de cultivo de Paralabrax maculatofasciatus}

La cabrilla arenera Paralabrax maculatofasciatus es producida a escala piloto en las instalaciones del Centro Interdisciplinario de Ciencias Marinas (CICIMAR). Los reproductores son capturados del medio natural usando piola y anzuelo; en el laboratorio el desove es inducido mediante control ambiental. Ambos, el desove y la crianza hasta juveniles $(c a .10 \mathrm{~cm})$ se realiza en instalaciones controladas usando sistemas de agua en recirculación y la engorda es realizada en jaulas flotantes. Cada sistema de recirculación está equipado con filtros mecánicos y biológicos, espumador, luz UV y control artificial de fotoperiodo y temperatura. Cada tanque está provisto de aireación a través de difusores centrales mediante sopladora. Los reproductores son mantenidos en tanques de $1100 \mathrm{~L}$ (aprox. $1.5 \mathrm{~g} \mathrm{~L}^{-1}$ ). Los peces son alimentados adlibitum una vez por día con calamar y pescado congelados, los remanentes de alimento y los desechos fecales son extraídos manualmente.

\section{Muestreo}

El estudio fue realizado entre 1991 y 1996 en las instalaciones de CICIMAR. Cada infección y brote que ocurrió 
conditions. Skin lessions, gills, eyes and blood samples, and swabs of liver and kidney were cultured directly on triplicate plates of Marine Agar 2216, tripticase soy agar (TSA, Bioxon), and thiosulfate-citrate-bile-sucrose agar (TCBS, Difco). Plates were incubated at $25^{\circ} \mathrm{C}$ and $35^{\circ} \mathrm{C}$ for 24 to $48 \mathrm{~h}$. Colony types were isolated and pure cultures were obtained by successive transfers to fresh media.

Pure cultures were subjected to taxonomic analysis using the standard morphological and biochemical tests following the procedures described by MacFaddin (1980) and Lányi (1987). Negative responses were confirmed by increasing the saline concentration in the media to $2.5 \% \mathrm{NaCl}$. The morphology and motility of isolates were microscopically determined by the Gram stain and the hanging-drop suspension, respectively. Growth at $42^{\circ} \mathrm{C}$ was tested on Marine Agar 2216 plates. Growth at $0.5,3,6,8$, and $10 \% \mathrm{NaCl}$ was undertaken in suitably modified Marine Broth. Every test was incubated at $30^{\circ} \mathrm{C}$ for the specific time required in accordance with Lányi (1987). To provide a presumptive identification, the biochemical profiles of isolates were compared to the diagnostic tables of Baumann and Schubert (1984), MacFaddin (1980), Austin and Austin (1987), Hendrie and Shewan (1979), and Frerichs (1984). The API-NFT (Api system ${ }^{\circledR}$ ) was used to complete the biochemical characterization and to corroborate the presumptive identification. The salinity of the basal media was adjusted to $2.5 \% \mathrm{NaCl}$.

\section{Pathogenicity test}

The vibrios isolated during hemorrhagic outbreaks (strains $\mathrm{VPb}-\mathrm{C} 4, \mathrm{VPb}-\mathrm{C} 7, \mathrm{VPb}-\mathrm{C} 8$, and $\mathrm{VPb}-10)$ were tested for pathogenicity using spotted sand bass (mean weight $6.84 \mathrm{~g}$ and mean SL $65.25 \mathrm{~mm}$ ). Fish were reared in UV-sterilized water at the CICIMAR facilities. Fish were held in 100-L aquariums with aeration and controlled temperature.

For each strain, groups of fifteen fish were intraperitoneally injected with $0.1 \mathrm{~mL}$ of bacterial suspension. Suspensions were prepared at $10^{4}, 10^{5}, 10^{6}, 10^{7}$, and $10^{8}$ viable bacterial cells $\mathrm{m}^{-1}$ with 24-h cultures in phosphate-buffered saline solution (PBS), $0.85 \% \mathrm{NaCl}, \mathrm{pH}$ 7.5. The total concentration in each suspension was estimated photometrically and by standard plate counts to determine the dose of bacteria with which fish were inoculated. Experimental controls were fifteen fish injected with $0.1 \mathrm{~mL}$ of sterile PBS and fifteen fish not injected.

Symptoms developed during infection were recorded for 20 days. The aquarium water was changed daily and fresh fishmeal was provided as food. Moribund fish were bacteriologically analysed as previously described.

Differential leukocyte counts were made in samples of blood removed from the caudal vein. Two slides were prepared with each blood sample and all slides were dyed with Wright stain (Merck). Samples were taken prior to injection and compared with samples of fish with apparent symptoms of disease. Counts were made by using a $1000 \times$ light microscope. The en los juveniles y reproductores fue analizado rutinariamente. En este reporte no se consideraron las infecciones no asociadas con el género Vibrio.

En el laboratorio, los peces enfermos fueron anestesiados con MS222 (Tricaine Spectrum ${ }^{\circledR}$ ) y disectados en condiciones asépticas. Se cultivaron muestras de piel lesionada, branquias, ojos y sangre, así como frotis de hígado y riñón directamente sobre placas de Agar Marino 2216, Agar tripticasa de soya (TSA, Bioxon) y Agar Tiosulfato-Citrato-Bilis-Sucrosa (TCBS, Difco). Las placas fueron incubadas a $25^{\circ} \mathrm{C}$ y $35^{\circ} \mathrm{C}$, durante 24 a $48 \mathrm{~h}$. Se aislaron colonias representativas de cada tipo y se obtuvieron cultivos puros mediante su transferencia a medio nuevo.

Los cultivos puros fueron sujetos a análisis taxonómico usando las pruebas morfológicas y bioquímicas estándar descritas por MacFaddin (1980) y Lányi (1987). Las respuestas negativas fueron confirmadas incrementando la concentración salina de los medios a $2.5 \% \mathrm{NaCl}$. La morfología y movilidad de las cepas aisladas fueron determinadas al microscopio mediante las técnicas de tinción de Gram y la técnica de la gota suspendida (hanging-drop) respectivamente. El crecimiento a $42^{\circ} \mathrm{C}$ fue evaluado sobre placas de Agar Marino 2216. El crecimiento a $0.5,3,6,8$ y $10 \% \mathrm{NaCl}$ fue realizado en Caldo Marino con salinidad ajustada. Cada una de las pruebas fue incubada a $30^{\circ} \mathrm{C}$ por el tiempo requerido, de acuerdo con Lányi (1987). Para proporcionar una identificación presuntiva, se compararon los perfiles bioquímicos de las cepas aisladas con las tablas diagnósticas de Baumann y Schubert (1984), MacFaddin (1980), Austin y Austin (1987), Hendrie y Shewan (1979) y Frerichs (1984). El sistema de multipruebas API-NFT (Api system ${ }^{\circledR}$ ) fue utilizado para completar la caracterización bioquímica y para corroborar la identificación. La salinidad del medio basal fue ajustada a $2.5 \% \mathrm{NaCl}$.

Pruebas de patogenicidad

La patogenicidad de los vibrios aislados durante los brotes hemorrágicos (cepas $\mathrm{VPb}-\mathrm{C} 4, \mathrm{VPb}-\mathrm{C} 7, \mathrm{VPb}-\mathrm{C} 8$ y $\mathrm{VPb}-10$ ) fue evaluada usando cabrillas (con peso medio de $6.84 \mathrm{~g}$ y longitud estándar de $65.25 \mathrm{~mm}$ ). Los peces fueron criados en agua de mar esterilizada en las instalaciones de investigación del CICIMAR. Los peces fueron mantenidos en acuarios de $100 \mathrm{~L}$ con aireación y temperatura controlada.

Por cada cepa, se intectaron por vía intraperitoneal con $0.1 \mathrm{~mL}$ de suspensión bacteriana grupos de quince peces. Las suspensiones fueron preparadas a concentraciones de $10^{4}, 10^{5}$, $10^{6}, 10^{7}$ y $10^{8}$ células viables $/ \mathrm{ml}$ de cultivo de $24-\mathrm{h}$ en solución salina amortiguada con fosfatos (PBS) a $0.85 \% \mathrm{NaCl}$ y $\mathrm{pH} 7.5$. La concentración total en cada suspensión fue estimada fotométricamente y mediante conteo estándar en placa para determinar la dosis a la cual los peces fueron inoculados. Los controles del experimento fueron quince peces inyectados con $0.1 \mathrm{~mL}$ de PBS estéril y quince peces no inyectados.

Los síntomas desarrollados durante la infección fueron registrados por 20 días. El agua de los acuarios fue cambiada 
identification of the white blood cells was made using the descriptions by Roberts (1978), Gromon (1982), Yasutake and Wales (1983), and Houston (1990). The difference in the percentages of healthy and diseased fish was evaluated by the non-parametric U-Mann-Whitney and the Wilcoxon tests (Sokal and Rolf, 1981).

\section{Results}

\section{Incidence of Vibrio}

During our study, Vibrio spp. were isolated several times associated with infections of the spotted sand bass. Most were isolated from infections of wounds caused by parasites or handling. However, two septicemic outbreaks occurred during the summers of 1991 and 1992 in which a Vibrio sp. was considered to be the principal etiologic agent. Table 1 summarizes the characteristics of the bacteria associated to outbreakes and mortality.

A total of 59 strains of Vibrio were isolated from focal and systemic infections. According to the differences in their biochemical profile, the isolates of $V$. alginolyticus were separated into four groups. The groups differed mainly in their ability to use carbohydrates as sole carbon source.

The isolated strains that grew on TCBS were Gramnegative, straight rods, motile, and oxidase and catalasepositive, were initially considered as Vibrio. The isolates were identified as $V$. alginolyticus, $V$. vulnificus, $V$. parahaemolyticus, V. cholerae, V. fluvialis, and Vibrio sp. and, in most cases, the presumptive identification was corroborated with API-NFT. Some strains were identified only at genus level using the database of API-NFT and were biochemically very close to V. parahaemolyticus. However, one strain (named Vibrio sp2) could not be identified as any particular species.

Figure 1 summarizes the number of events, per month, from 1991 to 1995 in which each species was isolated from infected fish. Vibrio were present during throughout the year associated with spotted sand bass disease. Vibrio alginolyticus was the most frequently isolated bacteria during our study, and was present in fish with focal and systemic infections occurring as dominant flora of external wounds and ulcers. Vibrio vulnificus was similarly isolated throughout the year but was present only in external ulcers.

Vibrio parahaemolyticus, V. cholerae, V. fluvialis, and Vibrio sp. occurred occasionally in external wounds but mainly in mixed cultures during Autumn and Winter (fig. 1).

During June-July 1991 and August-September 1992, two outbreaks of Vibrio spp. occurred at the CICIMAR facilities, both affecting the broodstock of spotted sand bass. In 1991, the mortality reached $60 \%$, and during 1992 all the broodstock was lost. The Vibrio outbreak occurrence was associated with an infestation of Cryptocarion irritans that occurred prior to vibriosis during 1991 and with temperatures higher than $27^{\circ} \mathrm{C}$ during the Summer 1992. diariamente y se proporcionaron trozos de pescado fresco como alimento. Los peces moribundos fueron analizados bacteriológicamente como se describió anteriormente.

Se realizaron conteos diferenciales de leucocitos con sangre extraida de la vena caudal. Con cada muestra de sangre se prepararon dos laminillas, las cuales fueron teñidas con tinción de Wright (Merk). Las muestras de sangre fueron obtenidas antes de la inyección y comparadas con muestras de peces con síntomas de enfermedad. Los conteos fueron realizados usando un microscopio óptico a 1000×. La identificación de las células blancas de la sangre se realizo con base en las descripciones de Roberts (1978), Gromon (1982), Yasutake y Wales (1983) y Houston (1990). La diferencia entre los porcentajes registrados para peces sanos y enfermos fue evaluada mediante las pruebas no paramétricas U-Mann-Whitney y Wilcoxon (Sokal y Rolf, 1981).

\section{Resultados}

\section{Incidencia de Vibrio}

Durante nuestro estudio, en multiples ocasiones se aisló Vibrio asociado con infecciones de la cabrilla arenera. La mayoría de las bacterias fueron aisladas a partir de heridas causadas por parásitos o manipulación, sin embargo, dos brotes septicémicos ocurrieron durante el verano de 1991 y 1992, en los cuales un Vibrio sp fue considerado el principal agente etiológico. La tabla 1 resume las características de las bacterias asociadas a los brotes y a mortalidad.

En total 59 cepas de Vibrio fueron aisladas de infecciones focales y sistémicas. Las cepas de V. alginolyticus fueron separadas en cuatro grupos de acuerdo a las diferencias en su perfil de respuesta bioquímica. Los grupos diferían entres sí principalmente en su capacidad para utilizar algunos carbohidratos como única fuente de carbón.

Inicialmente fueron consideradas como Vibrio las cepas aisladas que crecieron en TCBS, resultaron Gram-negativas y fueron bacilos curvos, móviles y positivos a la producción de catalasa y oxidasa. Las cepas aisladas fueron identificadas como V. alginolyticus, V. vulnificus, V. parahaemolyticus, V. cholerae, V.fluvialis y Vibrio sp. En la mayoría de los casos, la identificación presuntiva fue ratificada con API-NFT. Algunas cepas fueron identificadas solo a nivel género, usando la base de datos de API-NFT, y resultaron bioquímicamente muy parecidas a V. parahaemolyticus. Sin embargo, una cepa (denominada Vibrio sp2) no pudo ser identificada como ninguna especie en particular.

La figura 1 resume el número de eventos por mes, desde 1991 a 1995, en los que cada especie fue aislada de peces afectados. Los vibrios estuvieron presentes durante todo el año asociados con enfermedades de la cabrilla arenera. Vibrio alginolyticus fue la especie mas frecuentemente aislada durante nuestro estudio y estuvo presente tanto en peces con infecciones focales como durante infecciones sistémicas apareciendo como flora dominante en heridas externas y 
Table 1. Characteristics of isolates during outbreaks of vibriosis of Paralabrax maculatofasciatus.

Tabla 1. Características de los cultivos aislados durante los brotes de vibriosis en Paralabrax maculatofasciatus.

\begin{tabular}{|c|c|c|c|c|c|c|c|}
\hline Strain & $\mathrm{VPb}-\mathrm{C} 7$ & $\mathrm{VPb}-\mathrm{C} 10$ & $\mathrm{VPb}-\mathrm{C} 4$ & Strain & $\mathrm{VPb}-\mathrm{C} 7$ & $\mathrm{VPb}-\mathrm{C} 10$ & $\mathrm{VPb}-\mathrm{C} 4$ \\
\hline Presumptive ID & $\begin{array}{c}\text { Vibrio } \\
\text { alginolyticus }\end{array}$ & $\begin{array}{c}\text { Vibrio } \\
\text { vulnificus }\end{array}$ & $\begin{array}{l}\text { Vibrio } \\
\text { sp. }\end{array}$ & Presumptive ID & $\begin{array}{c}\text { Vibrio } \\
\text { alginolyticus }\end{array}$ & $\begin{array}{c}\text { Vibrio } \\
\text { vulnificus }\end{array}$ & $\begin{array}{l}\text { Vibrio } \\
\text { sp. }\end{array}$ \\
\hline Cell morphology & $\mathrm{R}$ & $\mathrm{R}$ & $\mathrm{R}$ & Production of & & & \\
\hline Swarming on TSA & + & - & - & $\beta$-Galactosidase & - & + & + \\
\hline Pigmentation & - & - & - & Arginine dihydrolase & - & - & - \\
\hline Capsule & - & - & - & Catalase & + & + & + \\
\hline Gram stain & - & - & - & Gelatinase & + & + & + \\
\hline Motility & + & + & + & Lysine decarboxylase & + & + & + \\
\hline $\mathrm{O} / \mathrm{F}$ Glucose & $\mathrm{F}$ & $\mathrm{F}$ & $\mathrm{F}$ & Ornithine decarboxyase & + & + & + \\
\hline Methyl red & + & + & + & Oxidase & + & + & + \\
\hline Nitrate Reduction & + & + & + & Tryptophane deaminase & + & + & + \\
\hline Voges-Proskauer & - & - & - & Urease & - & - & - \\
\hline TSI (EP) test & $\mathrm{k} / \mathrm{a}$ & $\mathrm{k} / \mathrm{a}$ & $\mathrm{k} / \mathrm{a}$ & Aesculin hydrolysis & + & + & + \\
\hline KIA (EP) test & $\mathrm{k} / \mathrm{a}$ & $\mathrm{k} / \mathrm{a}$ & $\mathrm{k} / \mathrm{a}$ & Use of & & & \\
\hline Citrate (Simmons) & + & + & + & Adipate & - & - & - \\
\hline Gas production & + & + & - & Arabinose $(\mathrm{L}+)$ & - & - & - \\
\hline Growth at $42^{\circ} \mathrm{C}$ & + & + & + & Caprate & - & - & - \\
\hline Growth in & & & & Glucose & - & - & + \\
\hline TCBS & + & + & + & Gluconate & - & - & + \\
\hline $0.5 \% \mathrm{NaCl}$ & \pm & + & + & Malate (L) & + & + & + \\
\hline $3 \% \mathrm{NaCl}$ & + & + & + & Maltose & + & + & + \\
\hline $6 \% \mathrm{NaCl}$ & + & + & + & Mannitol & + & - & + \\
\hline $8 \% \mathrm{NaCl}$ & + & + & + & Mannose & + & - & + \\
\hline \multirow[t]{2}{*}{$10 \% \mathrm{NaCl}$} & + & + & + & Phenyl acetate & - & - & - \\
\hline & & & & N-Acetyl-D-Glucosamine & + & - & + \\
\hline
\end{tabular}

$+=$ positive or successful response,$-=$ negative or unsuccessful response, $\pm=$ positive or negative, $\mathrm{k}=$ alkaline, $\mathrm{a}=$ acid, $\mathrm{F}=$ fermentative, $\mathrm{O}=\mathrm{oxidative}$.

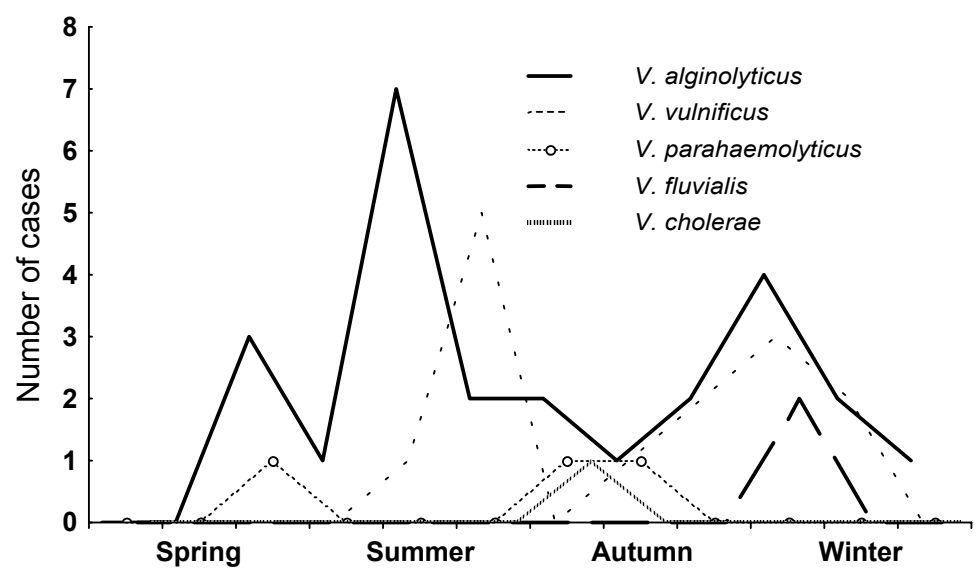

Figure 1. Number of cases in which species of vibrio were asociated with infections of Paralabrax maculatofasciatus. Data from 1991 to 1996.

Figura 1. Número de casos en los que Vibrio sp estuvieron asociadas con infecciones de Paralabrax maculatofasciatus. Datos de 1991 a 1996. 
Gross pathology of septicaemic fish

During the outbreaks, affected fish became inactive, torpid, anorexic, and increased their opercular breathing movements. Externally, the skin tended to darken, and the scales became loose. Lesions included petechiae, dermal hemorrhages, and ulceration, mainly in the pelvic fin region and anus. A narrow zone of hyperemia could be seen around the ulcers. Severe hemorrhages and erosion were present on the fins. In some fish, there was erosion on the lateral line and opaqueness in the eyes. Internally, pale liver and hemorrhages on the gas bladder and intestines were observed. The intestine was seen distended and filled with a clear viscous fluid, especially in the rectal region.

The isolates recovered during the outbreaks were Gramnegative motile rod-shaped organisms $(c a .1 \mu \mathrm{m} \times 3 \mu \mathrm{m})$. TCBS cultures had many medium-sized (4 to $6 \mathrm{~mm}$ ) yellow, convex colonies, surrounded by a yellow clear zone. All isolates grew well at $25^{\circ} \mathrm{C}$ or $35^{\circ} \mathrm{C}$. The bacterial isolates were identified as Vibrio alginolyticus, V. vulnificus, and Vibrio sp. and were isolated from wounds and external ulcers. Vibrio alginolyticus was also isolated in pure cultures from internal injuries, blood, liver and kidney of moribund fish.

\section{Pathogenicity test}

No gross changes were observed at any of the concentrations tested in fish inoculated with strains $\mathrm{VPb}-\mathrm{C} 4$ (Vibrio sp.) and $\mathrm{VPb}-\mathrm{C} 8$ (V. alginolyticus). The fish inoculated with strain $\mathrm{VPb}-\mathrm{C} 10$ ( $V$. vulnificus) tended to rest on the bottom of the aquarium, increasing their opercular breathing movements. On the third day postinoculation, they returned to normality and mortality did not occur. In fish inoculated with strain $\mathrm{VPb}-\mathrm{C} 7$ (V. alginolyticus) at concentrations of $10^{5}, 10^{6}$, and $10^{7}$ cells $\mathrm{mL}^{-1}$, lethargy and hemorrhages were observed during the first few days. However, fish recovered completely at day 13 and mortality did not occur. The fish inoculated with $10^{8}$ cells $\mathrm{mL}^{-1}$ of the strain $\mathrm{VPb}-\mathrm{C} 7$ did not accept any food at day 11. They had quick opercular breathing movements and petechiae were observed on the skin. On days 12 and 13, hemorrhages on the pectoral fins, eyes and the internal side of the operculum were observed. At the moment of the death (between days 12 and 14), the intestine was seen full of a transparent fluid and a pale liver was observed. Vibrio alginolyticus was isolated in pure cultures from kidney, liver, and stomach. Only six of the fifteen fish died within 20 days of the challenge.

Significant differences in leukocyte percentages were observed beetween healthy and challenged fish (table 2). In the challenged fish, there was a decrease in the percentage of lymphocytes, thrombocytes and granulocytes and an increase in the percentage of monocytes and macrophages. ulceras. De manera similar, Vibrio vulnificus fue aislado durante todo el año, pero sólo estuvo presente en heridas externas.

Vibrio parahaemolyticus, V. cholerae, V. fluvialis, y Vibrio sp. occurrieron ocasionalmente en heridas externas pero principalmente de manera mezclada durante otoño e invierno (fig. 1).

Durante los periodos de junio-julio de 1991 y de agostoseptiembre de 1992, dos brotes de Vibrio spp. ocurrieron en las instalaciones de CICIMAR, afectando ambos los reproductores de cabrilla. En 1991, la mortalidad llego al 60\% y durante 1992 todos los reproductores murieron. La aparición de brotes de Vibrio, fue asociada con una infestación previa de Cryptocarion irritans durante el brote de 1991 y con temperaturas superiores a $27^{\circ} \mathrm{C}$ durante el verano de 1992 .

\section{Signos externos de peces con septicemia}

Durante los brotes, los peces se tornaron inactivos, letárgicos, anoréxicos e incrementaron sus movimientos operculares de respiración. Externamente, la piel tendió a obscurecerse y las escamas a perderse. Las lesiones incluyeron petequia, hemorragias dérmicas y ulceraciones, principalmente en las aletas pélvicas y región anal. Alrededor de las úlceras se observó una franja de hiperemia. En las aletas se presentaron hemorragias severas y erosión. En algunos peces, se presentaron erosión de la línea lateral y opacidad en los ojos. Internamente se observaron el hígado decolorado y hemorragias sobre la vejiga gaseosa e intestinos. El intestino estaba lleno de un fluido viscoso transparente, especialmente hacia la región rectal.

Durante los brotes se aislaron bacilos Gram-negativos móviles (aprox. $1 \mu \mathrm{m} \times 3 \mu \mathrm{m}$ ). Los cultivos en TCBS presentaban abundantes colonias amarillas convexas de tamaño mediano $(4 \mathrm{a} 6 \mathrm{~mm})$, rodeadas por una región amarilla clara. Todas las bacterias aisladas mostraron un buen crecimiento a $25^{\circ} \mathrm{C}$ o $35^{\circ} \mathrm{C}$. Las bacterias aisladas fueron identificadas como Vibrio alginolyticus, $V$. vulnificus, y Vibrio sp y fueron aisladas a partir de heridas y úlceras externas. Vibrio alginolyticus, fue aislada también como cultivo puro de lesiones internas, sangre, hígado y riñón de peces moribundos.

\section{Pruebas de patogenicidad}

No se observaron cambios en los peces inoculados con las cepas $\mathrm{VPb}-\mathrm{C} 4$ (Vibrio sp.) y $\mathrm{VPb}-\mathrm{C} 8$ (V. alginolyticus). Los peces inoculados con las cepas $\mathrm{VPb}-\mathrm{C} 10$ (V. vulnificus) tendieron a aletargarse en el fondo del acuario e incrementaron su frecuencia de ventilación. Los peces regresaron a la normalidad tres días después de la inoculacióny no se registro mortalidad. Se observó aletargamiento en los peces inoculados con la cepa $\mathrm{VPb}-\mathrm{C} 7$ ( $V$. alginolyticus) a concentraciones de $10^{5}, 10^{6}$ y $10^{7}$ celulas $\mathrm{mL}^{-1}$ y se presentaron hemorragias durante los primeros días posteriores a la inoculación. Sin embargo, los peces se recuperaron completamente para el día 13 posterior a la inoculación sin registrarse mortalidad. Los 


\section{Discussion}

The Vibrio species found in spotted sand bass had previously been reported as fish pathogens (Muroga et al., 1979; Colorni et al., 1981; Tison et al., 1982; Austin and Gibb, 1993; Zhan and Bohai, 1994). Most occurred as opportunistic invaders in lesions provoked by physical damage caused during handling or by parasitic infection.

In fish, vibriosis has been described as a stress-dependent disease with global distribution (Austin and Austin 1987). However, different cultured fishes have been affected differently by each species of Vibrio reported as a fish pathogen. The severity of the damage caused can depend on the particular conditions of culture, and the natural susceptibility of the fish species (Balfry et al., 1994). Listonella anguillarum formally Vibrio anguillarum, has been considered as the most dangerous species for fish. The economic losses caused in fish production by $L$. anguillarum have led to the necessary development of costly preventive measures (such as vaccination) to diminish its adverse effects. However, L. anguillarum has not been reported as a pathogen for all cultured fishes and in the cultures from infected spotted sand bass there was no evidence of L. anguillarum. Neither It was isolated during the five years of the present study.

Artificial conditions have been used for spotted sand bass culture in order to diminish the effect of environmental changes. However, in the present study, Vibrio infections occurred most frequently during the warmer months from 1991 to 1996 and the presence of the different species of Vibrio displayed a seasonal occurrence, probably as a consequence of the natural intake of bacteria in the culture water. These seasonal variations can reflect changes in natural bacterial populations (Austin and Austin, 1987).

During the pathogenicity test, only the strain $\mathrm{CPb}-07$ ( $V$. alginolyticus) isolated during an outbreak could produce clinical signs and mortality in the spotted sand bass. The mortality was recorded at a $10^{8}$ cells $\mathrm{mL}^{-1}$ density and only 6 of the 15 fish inoculated died after 20 days. The density used is very high and, by itself, does not explain the outbreak occurrence because these numbers do not occur naturally at the rearing facility.

During the septicemic outbreaks, $V$. alginolyticus was isolated in pure cultures from the blood. However, in our experimental trials bacteremia was not found. Some changes were observed in the percentages of leukocytes. In fishes, changes in the numbers of blood cells have been reported during bacterial infections (Ransom et al., 1984; Lewis, 1985; Lehmann et al., 1989) which, in some cases, were correlated with the presence of bacteria in the blood stream. The accurate meaning of these differences is uncertain but it can be due to the immune response, or to extracellular factors such as toxins or enzymes produced by bacteria (Inamura et al., 1985; Notage and Birkbeck, 1987a,b). Further research is necessary to know if the virulence factors of $V$. alginolyticus are responsible of this pathological changes. peces inoculados con $10^{8}$ celulas $\mathrm{mL}^{-1}$ de la cepa $\mathrm{VPb}-\mathrm{C} 7$ dejaron de aceptar alimentos al día 11 , su ventilación opercular se incrementó y se observó petequia en la superficie corporal. Para los días 12 y 13, se observó la aparición de hemorragias sobre las aletas, ojos y parte interna del opérculo. Al momento de la muerte (entre los días 12 y 14), se observó el intestino lleno de un líquido transparente y el hígado se había decolorado. Vibrio alginolyticus se aisló en como cultivo puro de hígado, riñón y estomago. Solo seis de los quince peces, murieron dentro de los 20 días que duró el experimento.

Se encontraron diferencias significativas en los porcentajes de leucocitos en peces sanos e infectados (tabla 2). En los peces infectados, se observó una disminución en los porcentajes de linfocitos, trombocitos y granulocitos así como un incremento en el porcentaje de monocitos y macrófagos.

\section{Discusión}

Las especies de Vibrio encontradas en la cabrilla arenera han sido reportadas previamente como patógenos de peces (Muroga et al., 1979; Colorni et al., 1981; Tison et al., 1982; Austin y Gibb, 1993; Zhan y Bohai, 1994). La mayoría de ellas ocurren como invasores oportunistas en lesiones provocadas por daño físico durante la manipulación o por infestación de parásitos.

La vibriosis ha sido descrita como una enfermedad de distribución mundial en peces que depende del estrés (Austin y Austin, 1987). Sin embargo, las diferentes especies de peces son afectadas de manera diferencial por cada especie de Vibrio reportada como agente patógeno de peces. La severidad de los daños causados puede depender de las condiciones particulares de cultivo y de la susceptibilidad natural de cada especie de pez (Balfry et al., 1994). Listonella anguillarum, formalmente Vibrio anguillarum, ha sido considerada como la especie más peligrosa para los peces. Las pérdidas económicas que L. anguillarum ha causado en la producción de peces han hecho necesario el desarrollo de costosas medidas preventivas (como la vacunación) para disminuir sus efectos adversos. Sin embargo, L. anguillarum no ha sido reportada como agente patógeno en todos los peces cultivados, y en la cabrilla arenera no encontramos evidencias de L. anguillarum en los cultivos obtenidos de peces infectados, ni tampoco fue aislada durante los cinco años del presente estudio.

En el cultivo de la cabrilla arenera se han usado condiciones artificiales con el propósito de disminuir el efecto de los cambios ambientales. Sin embargo, en el presente estudio, las infecciones por Vibrio ocurrieron más frecuentemente durante los meses de verano de 1991 a 1996, y la presencia de las diferentes especies de Vibrio mostró una ocurrencia estacional, probablemente como consecuencia de la entrada natural de bacterias en el agua de cultivo. Estas variaciones estacionales pueden a su vez reflejar los cambios en las poblaciones de bacterias en la naturaleza (Austin y Austin, 1987).

Durante las pruebas de patogenicidad, solo la cepa $\mathrm{CPb}-07$ ( $V$. alginolyticus) aislada durante un brote, produjo signos 
Table 2. Differential composition of the white blood cells in samples of Paralabrax maculatofasciatus, previous and after a challenge of pathogenicity.

Tabla 2. Composición diferenciada de los leucocitos en las muestras de Paralabrax maculatofasciatus, antes y después de las pruebas de patogenicidad.

\begin{tabular}{lccc}
\hline Cell type & $\begin{array}{c}\text { Healthy fish } \\
n=48\end{array}$ & $\begin{array}{c}\text { Challenged fish } \\
n=5\end{array}$ & Difference \\
\hline Lymphocytes & $41.4 \pm 11.4$ & $28.8 \pm 1.33$ & $* *$ \\
Thrombocytes & $47.2 \pm 10.2$ & $2.6 \pm 0.8$ & $* * *$ \\
Monocytes and Macrophages & $3.6 \pm 2.3$ & $70.4 \pm 2.15$ & $* * *$ \\
Granulocytes & $7.85 \pm 4.76$ & $2.2 \pm 2.86$ & $*$ \\
\hline
\end{tabular}

Values are given in percentages and represent means \pm SD. Asterisks indicate significant differences between healthy and challenged fish and thier meaning is: ${ }^{*}=P<0.05,{ }^{* *}=P<0.01,{ }^{* * *}=P<0.00$.

Vibrio alginolyticus has been reported associated to diseases in Mugil cephalus (Burke and Rodgers, 1981), Sparus aurata (Colorni et al., 1981), Cantigaster rostrata (Ventura and Albuquerque, 1983), Coryphaena hippurus (LeaMaster and Ostrowski, 1988), Scophthalmus maximus (Austin et al., 1993 ) and Epinephelus malabaricus (Lee 1995). However, the role of $V$. alginolyticus as a fish pathogen is not clear and its ability to cause disease has been associated with stress conditions or parasites (Burke and Rodgers, 1981; Austin and Austin, 1987). Additionally Austin and Austin (1994) did not find any evidence that $V$. alginolyticus was a pathogen for salmonids. In posterior studies, $V$. alginolyticus was described as a probiont capable of inhibiting pathogenic bacteria such as Aeromonas salmonicida, L. anguillarum, and $V$. ordalii and has been proposed as a biological control for microflora in shrimp cultures (Austin et al., 1995). In recent analyses of spotted sand bass, $V$. alginolyticus has been isolated as part of the microflora of healthy wild and cultured fishes since it has been found to be a normal inhabitant of all external surfaces and the gastrointestinal tract (Martínez-Díaz et al., 2000). Apparently the pathogenicity of $V$. alginolyticus for fish is influenced by the temperature because it has been reported as a tropical fish pathogen (Burke and Rodgers, 1981; Ventura and Albuquerque, 1983; LeaMaster and Ostrowski, 1988) or temperate water fishes exposed to abnormally high temperature (Austin et al., 1993). Further research is neccesary to know if the ability of $V$. alginolyticus to produce a septicemic outbreak in the spotted sand bass depends on other primary factors such as specific environmental conditions or the immune status of the fish.

Recently, the frequency and the severity of the vibriosis events in cultured spotted sand bass cultured at CICIMAR have been less than those at the beginning of the study. This is a consequence of some sanitary measures implemented mainly to enhance the water quality: the mechanical and biological filtering capacity was increased through the use of fluidized beds and the water exchange was diminished in order to avoid drastic variations in water temperature. Additionally the trash fish is frozen, at least for a week, before using it as food. clínicos y mortalidad en la cabrilla arenera. La mortalidad fue registrada a una densidad de $10^{8}$ células $\mathrm{mL}^{-1}$ y sólo 6 de los 15 peces inoculados, murieron después de 20 días. La densidad usada es muy alta, y por sí misma, no explica la aparición de los brotes, ya que estas cantidades no ocurren de manera natural en las instalaciones de cultivo.

Durante los brotes septicémicos, $V$. alginolyticus fue aislado como cultivo puro de la sangre. Sin embargo, durante la infección experimental no se registró bacteremia. Se observaron algunos cambios en los porcentajes de leucocitos. Previamente ya se han reportado cambios en el número de células sanguíneas durante infeccionas bacterianas en peces (Ransom et al., 1984; Lewis, 1985; Lehmann et al., 1989). En algunos casos, estos cambios fueron correlacionados con la presencia de bacterias en la sangre. El significado preciso de estas diferencias es incierto y puede deberse a la respuesta inmune, o a la presencia de factores extracelulares como toxinas y enzimas producidas por bacterias (Inamura et al., 1985; Notage y Birkbeck, 1987a,b). En el caso particular de V. alginolyticus es necesario conocer si los factores de virulencia son responsables de estos cambios patológicos.

Vibrio alginolyticus se ha reportado asociado a enfermedades de Mugil cephalus (Burke and Rodgers, 1981), Sparus aurata (Colorni et al., 1981), Cantigaster rostrata (Ventura y Albuquerque, 1983), Coryphaena hippurus (LeaMaster and Ostrowski, 1988), Scophthalmus maximus (Austin et al., 1993) y Epinephelus malabaricus (Lee, 1995). Sin embargo, el papel de $V$. alginolyticus como patógeno de peces no es claro y su capacidad para causar enfermedades ha sido asociada con condiciones estresantes o parásitos (Burke y Rodgers, 1981; Austin y Austin, 1987). De manera adicional, Austin y Austin (1994) no encontraron evidencias de que $V$. alginolyticus fuera patógeno para salmónidos; en estudios posteriores esta especie fue descrita como un probionte capaz de inhibir bacterias patógenas como Aeromonas salmonicida, L. anguillarum y $V$. ordalii, y ha sido propuesto como una forma de control biológico de la microflora de camarones cultivados (Austin et al., 1995). En análisis recientes de la cabrilla arenera, $V$. alginolyticus ha sido aislado como parte de la microflora de cabrillas silvestres y cultivadas, y ha sido encontrado como 


\section{Acknowledgements}

This work was supported by the Consejo Nacional de Ciencia y Tecnología (CONACyT). We thank Ellis Glazier for editing this English-language text.

\section{Referencias}

Álvarez-González, C.A., Ortiz-Galindo, J.L., Dumas, S., MartínezDíaz, S.F., Hernández-Ceballos, D., Grayeb-Del Alamo T., Moreno-Legorreta, M. and Peña-Martínez, R. (2001). Effect of stocking density on the growth and survival of spotted sand bass Paralabrax maculatofasciatus larvae in a closed recirculating system. J. World Aquacult. Soc., 32: 130-137.

Anguas-Vélez, B., Civera-Cerecedo, R., Cadena-Roa, M., Guillaume, J. and Martínez-Díaz, S.F. (2000). Studies on the nutrition of spotted sand bass Paralabrax maculatofasciatus: Effect of the dietary protein level on growth and protein utilization in juveniles fed semipurified diets. J. World Aquacult. Soc., 31: 580-591.

Austin, B. and Gibb, A. (1993). Emerging bacterial fish pathogens and their likely significance for aquaculture. Proceedings of the first international symposium on aquaculture technology and investment opportunities. Ministery of Agriculture and Water, Riyadh-Saudi Arabia. Pp 410-425.

Austin, B. and Austin, D.A. (1987). Bacterial fish pathogens: Disease in farmed and wild fish. Ellis Horwood Books Aquacult. Fish Support., Chichester (UK).

Austin, B., Stobie, M., Roberton, P.W.A., Glass, H.G., Stark, J.R. and Mundarris, M., (1993). Vibrio alginolyticus: The cause of gill disease leading to progresive low-level mortalities among juvenile turbot, Scophthalmus maximus L., in a scottish aquarium. J. Fish Dis., 16:3 277-280.

Austin, B., Stuckey, L.F., Robertson, P.A.W., Effendi, I. and Griffith, D.R.W. (1995). A probiotic strain of Vibrio alginolyticus effective in reducing diseases caused by Aeromonas salmonicida, Vibrio anguillarum and Vibrio ordalii. J. Fish Dis., 18(1): 93-96.

Austin, D.A. and Austin, B. (1994). The pathogenicity of Vibrio type strains to salmonids. International Symposium on Aquatic Animal Health: Program and Abstracts. Davis, CA, USA Univ. of California, School of Veterinary Medicine, pp. W 5.1

Balfry, S.K., Shariff, M., Evelyn ,T.P.T. and Iwama, G.K., (1994). The importance of the natural immune system in disease resistance of fishes, International symposium on aquatic animal healt: Program and abstracts. Davis, CA-USA. Univ. of California, Schol of Veterinary Medicine 1994, $110 \mathrm{pp}$

Baumann, P.S., and Schubert, R.H.W. (1984). The family Vibrionaceae Veron. In: Krieg, N. R. (ed.), Bergey's Manual of Systematic Bacteriology, vol 1, Wiliams \& Wilkins, Baltimore, pp. 515-538.

Burke, J. and Rodgers, L. (1981). Identification of pathogenic bacteria associated with the occurrence of 'red spot' in sea mullet, Mugil cephalus L. in South-Eastern Qeensland. J. Fish Dis., 3: 153-159.

Colorni, A., Paperna, I., and Gordin, H. (1981). Bacterial infections in gilt-head sea bream Sparus aurata cultured at Elat. Aquaculture, 23: 257-267.

Crosa, J.H., Schiewe, M.H. y Falkow, S. (1977). Evidence for plasmid contribution to the virulence of the fish pathogen Vibrio anguillarum. Infect. Immun, 18: 509-513. habitante normal de sus superficies externas y el tracto gastrointestinal (Martínez-Díaz et al., 2000). Aparentemente, la patogenicidad de $V$. alginolyticus en peces, es influenciada por la temperatura ya que sólo ha sido reportado como patógeno de peces tropicales (Burke y Rodgers, 1981; Ventura and Albuquerque, 1983; LeaMaster and Ostrowski, 1988) o en peces de aguas templadas expuestos a temperaturas anormalmente altas (Austin et al., 1993). Debido a ello, es necesario investigar si la capacidad de $V$. alginolyticus para producir un brote septicémico en la cabrilla arenera depende de otros factores primarios como alguna condición ambiental específica o el estado inmunológico de los peces.

En años recientes, la frecuencia y severidad de los eventos de vibriosis en el cultivo de la cabrilla arenera en CICIMAR han sido menores que al inicio del presente estudio. Ello es una consecuencia de algunas medidas sanitarias implementadas principalmente para mejorar la calidad del agua: se aumentó la capacidad de los filtros biológicos y mecánicos mediante el uso de lodos activados y los recambios de agua fueron minimizados con el propósito de evitar variaciones drásticas en la temperatura del agua. Adicionalmente, los peces que sirven de alimento son congelados al menos durante una semana antes de ser usados como alimento.

\section{Agradecimientos}

Este trabajo fue financiado por el Consejo Nacional de Ciencia y Tecnología (CONACYT). Agradecemos a Ellis Glazier la edición del texto en inglés.

Traducido al español por los autores.

Deniz, M.S., Real, F., Acosta, B., Acosta, F. y Oros, J. (1993). Vibrio harveyi como patógeno oportunista en dorada (Sparus aurata). In: A. Cervino, A. Landin, A. de Coo, A. Guerra y M. Torre (eds.) Actas del IV Congreso Nacional de Acuacultura. Pontevedra, Spain. Centro de Investigaciones Marinas. pp. 593-598.

Egidius, E., Wiik, R. Andersen, K., Hoff, K.A. and Hjeltnes, B. (1986). Vibrio salmonicida sp. nov., a new fish pathogen. Int. J. Syst. Bacteriol., 36: 518-520.

Frerichs, G.N. (1984). The isolation of fish bacterial pathogens. Institute of Aquaculture, University of Stirling, Scotland.

Grimes, D.J., Gruber, S.H. and May, E.B. (1985). Experimental infection of lemon sharks, Negaprion brevirostris (Poey), with Vibrio species. J. Fish Dis., 8. 173-180.

Gromon, D.B. (1982). Histology of the striped bass. American Fisheries Society. Monograph. No. 3, Maryland, 116 pp.

Hendrie, M.S. and Shewan, J.M. (1979). The identification of Pseudomonads. In: F.A. Skimer and D.W. Lovelock (eds.) Identification Methods for the Microbiologists. Academic Press, London, pp. 1-14

Houston, A.H. (1990). Blood and Circulation. In: C.B. Schrec and P.B. Moyle (eds.), Methods for Fish Biology. American Fisheries Society, Bethesda, Maryland, pp. 273-322.

Inamura, H., Nakai, T. and Muroga, K. (1985). An extracellular proteinase produced by Vibrio anguillarum. Bull. Jap. Soc. Sci. Fish., 51: 1915-1920. 
Ishimaru, K. and Muroga, K. (1997). Taxonomical re-examination of two pathogenic vibrio species isolated from milkfish and swimming crab. Fish Pathol., 32: 59-64.

Iwamoto, Y., Suzuki, Y., Kurita, A., Watanabe, Y., Shimizu, T., Ohgam, H. and Yanahihara, Y. (1995). Vibrio trachiuri sp. nov. a new species isolated from diseased japanese horse mackerel, Microbiol. Immunol, 39: 11, 831-837.

Lányi, B. (1987). Clasical and rapid identification methods for medically important bacteria, In: R.R. Colwell and R. Grigorova (eds.), Methods in Microbiology, Vol. 19 Current methods for classification and identification of microorganisms, Academic Press, London, pp. 1-67.

LeaMaster, B.R. and Ostrowski, A.C. (1988). Vibriosis in captive dolphins. The Progressive Fish Culturist 50: 251-254.

Lee, K.K. (1995). Pathogenesis studies on Vibrio alginolyticus in the grouper, Epinephelus malabaricus, Bloch et Schneider. Microb. Pathog., 19:1 38-48.

Lehmann, J., Stuerenberg, F.J., and Mock, D. (1989). Changes in the haemogram of the rainbow trout (Salmo gairdneri) following an experimental infection with a strain of Aeromonas salmonicida salmonicida. Fish Health Protection Strategies, pp. 259-284.

Lewis, D.H. (1985). Vibriosis in Channel catfish, Ictalurus punctatus (Rafinesque). J. Fish Dis., 8: 539-545.

Love, M., Teebken-Fisher, D., Hose J.E., Farmer III, J.J., Hickman, F.W. and Fanning, G.R. (1981). Vibrio damsela, a marine bacterium, causes skin ulcers on the damselfish Cromis punctipinnis. Science 214: 1139-1140.

MacFaddin, J.F. (1980). Pruebas bioquímicas para la identificación de bacterias de importancia clinica. Ed. Medic. Panamericana, Argentina.

Martínez-Díaz, S.F., Pérez-España, H, Martínez-Pecero, R., Rosales, M.O., Alvarado-Castillo, R. and Tucker, J.Jr. (2001). Spawning, early development and completion of the life cycle of spotted sand bass in the laboratory. J. World Aquacult. Soc. 32: 122-129.

Martínez-Díaz, S.F., Moreno-Legorreta, M., Álvarez-González, C.A., Dumas, S., Ortíz-Galindo, J.L. y Vázquez-Juárez, R., (2000). Efecto del ambiente microbiano sobre la adquisición de la microflora en larvas de la cabrilla arenera Paralabrax maculatofasciatus (Steindachner, 1868) (Percoidei: Serranidae). Memorias del VII Congreso Nacional de Ictiología. 21-24 Nov. 2000, México DF. 26-27 pp.
Muroga, K., Takahashi, S. y Yamanoi, H. (1979). Non-cholera Vibrio isolated from diseased ayu. Bull. Jap. Soc. Scient. Fish. 45, 829834.

Notage, A.S. and Birkbeck, T.H., (1987a). Purification of a proteinase produced by the bivalve pathogen Vibrio alginolyticus NCMB 1339. J. Fish Dis., 10: 211-220.

Notage, A.S. and Birkbeck, T.H. (1987b). Production of proteinase during experimental infection of Ostrea edulis L. larvae with Vibrio alginolyticus NCMB 1339 and the antigenic relationship between proteinase produced by marine vibrios pathogenic for fish and shellfish. J. Fish Dis., 10: 265-273.

Ransom, D.P., Lannan, C.N., Rohovec, J.S., and Fryer, J.L. (1984). Comparison of histopathology caused by Vibrio anguillarum and Vibrio ordalii in three species of Pacific salmon. J. Fish Dis., 7: $107-115$

Roberts, R.J. (1978). Patología de los Peces, Versión española de Blanco, C.M.C.(Ed), 1981. Ed Mundi-Prensa, Madrid, 365 pp.

Saeed, M.O. (1995). Association of Vibrio harveyi with mortalities in cultured marine fish in kuwait, Aquaculture, 136: 1-2, 21-29.

Sindermann, C.J. (1990). Principal diseases of marine fish and shellfish, Vol.1, Second edition. Academic Press, U.S.A., 521 pp.

Sneath, P.H.A. and Sokal, R.R. (1973). Numerical taxonomy. W.H. Freeman and Co. 573 pp.

Sokal, R.R. and Rolf, F.J., (1981). Biometry. Second ed. W.H. Freeman and Co. 859 pp.

Tison, D.L., Nishibuchi, M., Greenwood, J.D. and Seidler, R.J., (1982). Vibrio vulnificus biogrup 2: a new biogrup pathogenic for eels. Appl. Environ. Microbiol., 44, 640-646.

Ventura, M.T. and Albuquerque, M.T.F. (1983). Vibriosis in Canthigaster rostrata Bloch 1786 in Portugal, a case report. Repos. Trab. Inst. Nac. Vet. Portugal, 145: 123-128.

Xu, B., Zhan, Y., Yushen, W. y Taozhen, C. (1993). Studies on the taxonomy of pathogenic bacteria on the bacterial hemorragic septicemia in cultured fishes in freshwater, Acta Hidrobiol. Sin. shuishen shengwu xeubao, 17:3, 259-266.

Yasutake, W.T. and Wales, J.H. (1983). Microscopic anatomy of salmonids: An Atlas. USA Department of the Interior. Fish and Wildlife Service, Washington, $190 \mathrm{pp}$.

Zhan, Y. and Bohai, X. (1994). Observation of Vibrio fluvialis biovar III in tissues of infected silver carp (Hypophthalmichthys molitrix) using the fluorescent antibody technique, Acta Hidrobiol. Sin. shuishen shengwu xeubao, 18:1, 95-96. 